\title{
THE EFFECT OF INTERIOR DESIGN ON EMPLOYEE'S JOB SATISFACTION
}

\author{
Koya and Ishik university presidency offices as an example \\ Vian A. Shareef ${ }^{1}$, Husein A. Husien², Soran K. Omer ${ }^{3}$ \\ ${ }^{1,2}$ Department of Architecture, Faculty of Engineering, Koya University, \\ Koya KOY45, Kurdistan Region - F.R. Iraq. \\ ${ }^{3}$ Department of Administration and Economy, Faculty of Humanities and Social Sciences, \\ Koya University, Koya KOY45, Kurdistan Region - F.R. Iraq. \\ vian.ahmed@koyauniversity.org, husein.ali@koyauniversity.org, \\ soran.kakarash@koyauniversity.org
}

\section{Original Scientific Paper doi:10.5937/jouproman6-17038}

\begin{abstract}
This study investigates the impact of interior design on employee's job satisfaction, and it is an exploratory study about employee's opinion to their office interior design at the presidency offices of both Koya and Ishik universities. As well as interior design is as an independent variable and job satisfaction is as dependent variable.
\end{abstract}

A questionnaire is used and its involving of thirty one phrases. Also, the scope of the population exists the employees of Koya and Ishik university, which are selected randomly and have been returned and analyzed, the following appropriate. Furthermore, statistical methods are used to analyze data and to test research hypotheses such as, regression, model summary statistics, one-sample ttest, mean and standard deviation, in addition (ANOVA) using statistical software program (SPSS.v.20).The main result of the study is summarize the result that interior design has an effect on job satisfaction of employees specify the result in both universities.

Key words: Interior design, Job satisfaction.

\section{Introduction}

It is known that human being influenced by many physical, physiological, biologic and chemical factors such as light, sound, noise, color, temperature and arrangements at their home, in other words, through the development of forms and the contents of architecture, especially interior design for the various periods in all. Therefore, researchers generate multiple problems besides they are trying to accomplishment response through the study, in addition there are some questions that researchers try to get answer which including:

1- What are the effects of interior design on employee's job satisfaction in both Koya and Ishik universities?

2- Which components of interior design is more affect on employee's job satisfaction?

3- Which age of employees in both Koya and Ishik universities is more affected by office interior design components?

\section{Literature reviews 2.1 Interior design}

According to Gaing and Nguyen (2017) the interior design "is about taking overall view of the way that individuals use and enjoy the space that they inhabit. It is about finding and creating a cohesive answer to a set of problems and dressing the solution to unify and strengthen our experience of the space", and it's definite by the national council for interior design qualification (NCIDQ) as the art and science of understanding people's behavior to create functional spaces inside a building through creative and technical keys (El-Zeiny, 2013). 
On the other hand the good physical office arrangements help workers to perform their everyday jobs more quickly and its providing comfort as well influence the behavior and employees works (Kamarulzaman et al, 2011). And work place interior design is a key factor in job satisfaction. Similarly, it affects the way in which employee's work. Then it may enhance organizations success (El-Zeiny, 2013).

Furthermore, Gaing and Nguyen (2017), Leblebici (2012) and Kamarulzaman et al (2011) allocated the interior design components in to office lay out, furniture, comfort, cleanness communication, privacy, personal storage, music, natural lighting, artificial lighting, physical security, temperature, humidity, special arrangement, color, decorative scheme, water quality, outdoor view and presence of plants and flowers, ventilation and air quality, heating, acoustics and noise. Correspondingly, they are discovered that all of them have an influence on both job performance and productivity. Additionally, Mstafa (2017) presented that the indoor environmental quality (IEQ)which are include thermal comfort, indoor air quality, security and fire safety, acoustic comfort, and visual comfort.

Also Gutnick (2007) explained that good workplace design can make a large difference in staff satisfaction, motivation, attraction, and retention. Similarly it can affect the level of knowledge and skills of employees. By contrast, poor work place interior design is linked to subordinate business performance.

\subsection{Job satisfactions}

Job satisfaction is a general expression of staff's positive attitudes built up to their jobs, in addition it's known, job satisfaction has been a subject to scientific researches with "Hawthorn" studies in $20^{\text {th }}$ centuries. And it's defined as pleasurable or positive emotional state as a result of assessment of the job (Çelik, 2011) at the same time job satisfaction has been defined as an agreeable emotional state, consequent from the appraisal ones job experiences, as well as the point to which the employees expresses a positive affective positioning toward a job (Walker and Sorce, 2009).

In addition Neog and Bara (2014) outlined that there are many factors which are influenced employees job satisfaction and it's clear that has a positive and strong correlation between working environment and job satisfaction. Furthermore, Berghe (2011) focused on job satisfaction that it can see as an occupation of the features of a job, view of others, and employee's personality.

Moreover, the physical work environment has a great impact on their level of satisfaction. Subjects associated to comfort, communication, access and functional efficiency, taken together, were mentioned more than three times as frequently than were compensation, work hours and benefits or management. On the other hands the role of interior design consultant is critical to the improvement of an effective environment. "The quintessential office cannot be created without simultaneously designing physical, technical, social and organizational systems that are in harmony" (ASID, 2001).

\section{Methodology}

This study was hypothesized that employees are more satisfied with physical characteristics of their office when there are available and it has higher quality in interior design elements. In addition it's based on both field of architectural engineering and business administration research conducted in the both Koya and Ishik universities. 
And qualitative analytical method is used for gathering information in this study to approach the accurate results the data is analyzed using statistical program called SPSS. As a result, here are several hypotheses that can test such as:

H1. There are positive effects of interior design on job satisfaction, if $t \geq 3, p>.05$.

H2. May not have effect of interior design on job satisfaction, if $\mathrm{t} \leq 3, \mathrm{p}>.05$.

H3. All components of interior design have huge impact on job satisfaction for each Koya and Ishik university and vice versa.
H4. All age ranges may be affected by office interior design elements?

H5. All age sorts may be not affected by office interior design components?

The researcher used questionnaire tool, to measure the interior design elements and job satisfaction for the employees of Koya university presidency as a public sector see fig.1., and employees of the presidency of Ishik university as a private university see fig.2., also the researcher depended on lateral of theoretical study and previous studies about both interior design and employee's job satisfaction.

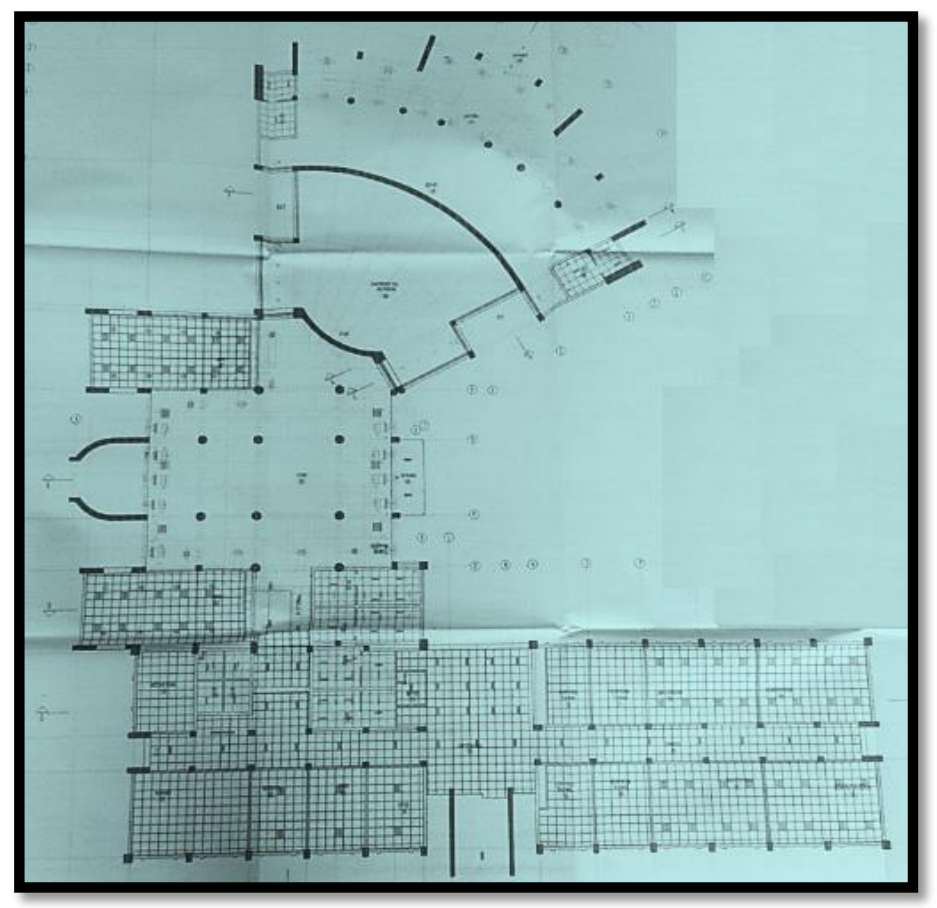

Fig.1. Plan of Koya university presidency building 


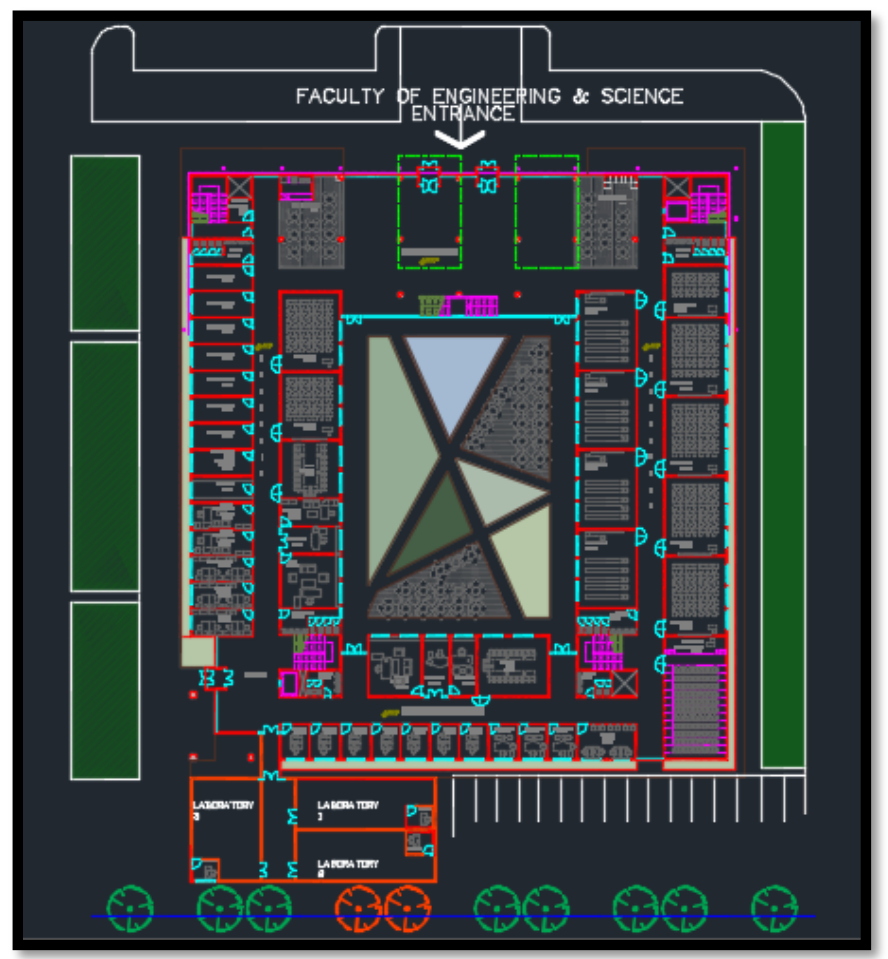

Fig.2. Plan of Ishik university building

The questionnaire is involved in the initial image on four pages and thirty one phrases and each of them has a given weight listed, On the other hand twenty one items direct towards of the dimensions of interior design, in addition the interior design as the independent variable in the study with the multiple ratios and numbers for each dimensions which has weights such as (extremely disagree $=1$, disagree $=2$, neutral $=3$, agree $=4$ extremely agree $=5$ ) at the test value 3 for all of them and it's as medium criteria. And if t. $3, p<.05$.

In addition, the content of the final pages form is competent to (job satisfaction) as a dependent variable in the study and contains 10 items. And in front of each phrases have this weights such as ( very few $=1$, few $=2$, average $=3$, many $=4$ and very much $=5$ ). At the test value 3 for all of them and it is the medium criteria, also if $\mathrm{t} .3 \mathrm{p}<.05$.

The result of the experimental study is summarized in the tables (1) which is indicate that the result fulfill the reliability of the sampling instrument.

On the other hand an alpha scores greater than (0.7) shows the internal consistency and sufficiency of the reliability of the hypothesis.

\section{Table 1. Reliability coefficient study tool through Cronbach alphas of questionnaire}

\begin{tabular}{|c|c|}
\hline Cronbach's Alpha & N of Items \\
\hline .913 & 35 \\
\hline
\end{tabular}




\section{Data collection and research findings}

Treatment was necessary statistical data to extract the numbers, and to estimates of the study sample to the availability of interior designing elements in both Koya and Ishik university offices see figures 3 and 4 below:

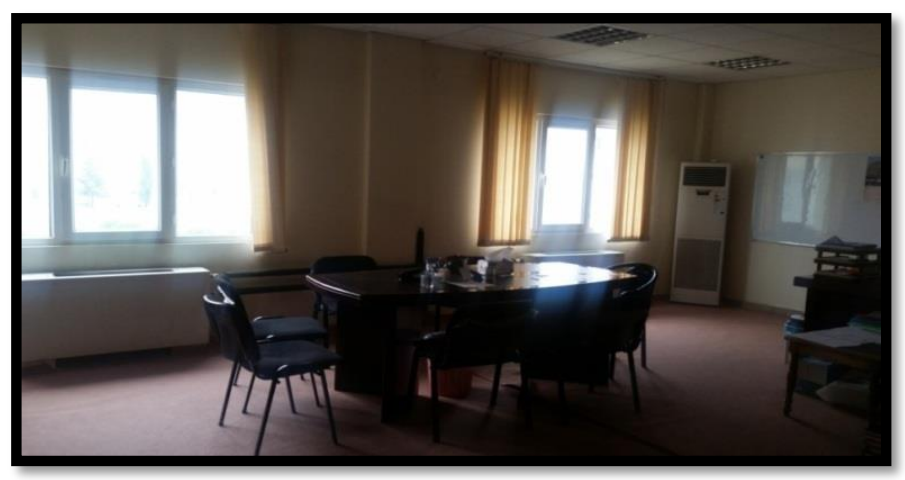

Fig.3. An interior office design of Koya university presidency

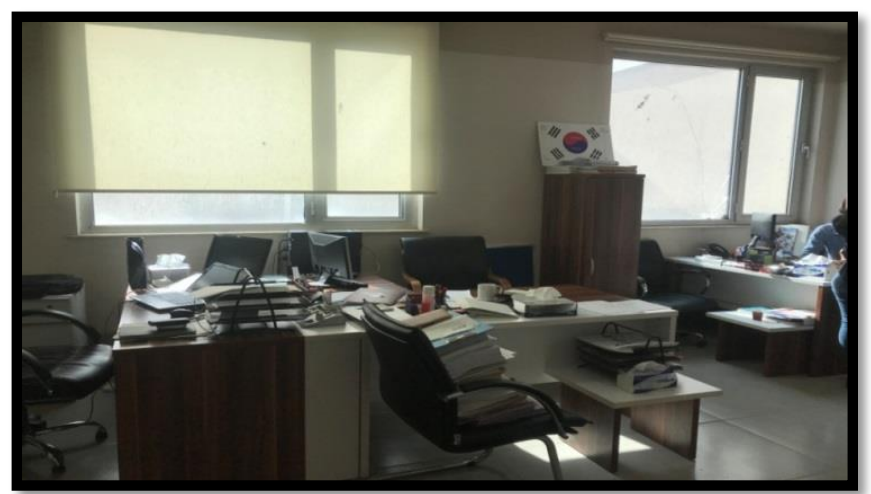

Fig.4. An interior office design of Ishik university's building

In addition, by the following statistical tests such as: regression, model summary statistics, one-sample t-test, also mean and standard deviation, in addition one way analysis of variance (ANOVA) using statistical software (SPSS).Also by using this program the data was analyzed to find and get several other results.

Tables (2) and (3) show the result of regression analysis, which demonstrate the dependence of overall job satisfaction (dependent variables) and interior design elements and (independent variables). Value $\mathrm{R}$ explains the strength of association between independent variables and dependent variables and $R$ value lies between $0-1$. The $\mathrm{R}$ value is.644 which is near 1 shows a strong association between independent variables and dependent variables and vice versa.

In addition, the results of the study illustrate that the regression analysis of interior design elements and overall job satisfaction is due to the interior design while remaining \%64.4 is an unexplained variability. $\mathrm{R}$ value as .644 shows a strong and significant $(\mathrm{F}=46.837, \mathrm{P}<.05)$ relationship between interior design components and overall job satisfaction. It means that interior design has an effect of job satisfaction of employee's through their offices in both Koya and Ishik universities. Also it's realized for first questions and first hypothesis (H1). 
Table 2. Regression of interior design and job satisfaction

\begin{tabular}{|ll|l|l|l|l|l|}
\hline Model & Sum of Squares & df & Mean Square & F & Sig. \\
\hline \multirow{3}{*}{1} & Regression & 2032.387 & 1 & 2032.387 & 46.837 & $.000^{\mathrm{b}}$ \\
& Residual & 2863.892 & 66 & 43.392 & & \\
& Total & 4896.279 & 67 & & & \\
\hline
\end{tabular}

a. Dependent Variable: JS

b. Predictors: (Constant), ID

*Item is significant between $0-1, p<0.05$.

Table 3. Model summary statistics of interior design elements

\begin{tabular}{|c|c|c|c|c|c|c|c|c|c|}
\hline \multirow[t]{2}{*}{ Model } & \multirow[t]{2}{*}{$\mathrm{R}$} & \multirow[t]{2}{*}{ R Square } & \multirow{2}{*}{$\begin{array}{l}\text { Adjusted } \\
\text { R Square }\end{array}$} & \multirow{2}{*}{$\begin{array}{l}\text { Std. Error } \\
\text { Of the Estimate }\end{array}$} & \multicolumn{5}{|c|}{ Change Statistics } \\
\hline & & & & & $\begin{array}{l}\text { R Square } \\
\text { Change }\end{array}$ & F Change & df1 & df2 & $\begin{array}{l}\text { Sig. F } \\
\text { Change }\end{array}$ \\
\hline 1 & $.644^{\mathrm{a}}$ & .415 & .406 & 6.58728 & .415 & 46.837 & 1 & 66 & .000 \\
\hline
\end{tabular}

a. Predictors: (Constant), ID

*Item is significant $\mathrm{p}<0.05$.

In addition, using one sample t-test for interior design elements in both Koya and Ishik university as well table (4) shows that 13 out of 21 elements of interior design are common in both Koya and Ishik university offices that were obtained by using mean and std. deviation and (t.3 p <0.05 level ). Also other elements don't share. Correspondingly, the most attractive element of interior design was (D10) which is expressing of adequate area of the window compare with the aria of space of room, because of the it has greater rate of mean (3.8529, P. .000) besides its (D9) with $(\mathrm{M}=3.7353, \mathrm{P}=.000)$ which is express on the amount of natural lighting, its truth because there are the constant correspondence between window ant the sunlight. On the other hands the poorer elements is availability prances of plants and flowers which are ignores from both Koya and Ishik university with mean rate $(\mathrm{M}=1.8971, \mathrm{P} .000)$. Then its test for third hypothesis.

Table 4. One-sample t-test for interior design elements in both Koya and Ishik University

\begin{tabular}{|l|c|c|c|r|r|c|}
\hline $\begin{array}{c}\text { Interior design } \\
\text { dimensions }\end{array}$ & $\mathbf{N}$ & Mean & $\begin{array}{c}\text { Std. } \\
\text { Deviation }\end{array}$ & $\mathbf{t}$ & $\mathbf{d f}$ & Sig. (2-tailed) \\
\hline D1 & 68 & 3.3235 & 1.12557 & 2.370 & 67 & .021 \\
\hline D2 & 68 & 2.8824 & 1.07244 & $-.905-$ & 67 & .369 \\
\hline D3 & 68 & 3.2794 & 1.07683 & 2.140 & 67 & .036 \\
\hline D4 & 68 & 3.5735 & 1.06947 & 4.422 & 67 & .000 \\
\hline D5 & 68 & 3.1618 & 1.21692 & 1.096 & 67 & .277 \\
\hline D6 & 68 & 3.0441 & .98396 & .370 & 67 & .713 \\
\hline D7 & 68 & 2.6765 & 1.29800 & $-2.055-$ & 67 & .044 \\
\hline D8 & 68 & 2.0000 & 1.05094 & $-7.847-$ & 67 & .000 \\
\hline D9 & 68 & 3.7353 & 1.24130 & 4.885 & 67 & .000 \\
\hline D10 & 68 & 3.8529 & 1.08263 & 6.497 & 67 & .000 \\
\hline D11 & 68 & 3.7647 & 1.17331 & 5.374 & 67 & .000 \\
\hline D12 & 68 & 2.9265 & 1.11055 & $-.546-$ & 67 & .587 \\
\hline D13 & 68 & 3.3382 & 1.04539 & 2.668 & 67 & .010 \\
\hline D14 & 68 & 3.0147 & 1.13942 & .106 & 67 & .916 \\
\hline D15 & 68 & 2.7941 & 1.12713 & $-1.506-$ & 67 & .137 \\
\hline
\end{tabular}




\begin{tabular}{|l|l|l|r|r|r|l|}
\hline D16 & 68 & 2.5147 & 1.13942 & $-3.512-$ & 67 & .001 \\
\hline D17 & 68 & 1.8971 & 1.16080 & $-7.835-$ & 67 & .000 \\
\hline D18 & 68 & 3.1765 & 1.15824 & 1.256 & 67 & .213 \\
\hline D19 & 68 & 3.3529 & 1.12985 & 2.576 & 67 & .012 \\
\hline D20 & 68 & 3.3235 & 1.05719 & 2.524 & 67 & .014 \\
\hline D21 & 68 & 2.8529 & 1.18781 & $-1.021-$ & 67 & .311 \\
\hline
\end{tabular}

*Item is significant at t.3 p $>0.05$ level (2-tailed).

* The abbreviation (D) is indicated of interior design dimension, for more clarify see appendix A

On the other hands, the results of the tables (5)and (6) shows that the most attractive element of interior design in Koya university was (D10 and D11) equally which is expressing of adequate area of the window compare with the aria of space of room and the location of window, because of the it has greater rates of mean (M=4.1622, P.000) .On the other hands inferior elements is availability prances of plants and flowers which are ignores from Koya university with mean rate $(1.7838$, P.000) reverse the (D17) . Then its test for (H3). Correspondingly, according to Ishik university results there are the same, while the rates are difference, however the most attractive component of interior design in Ishik university is (D9 and D10) equally which is stating of the amount of natural lighting and adequate area of the window, in compare with the area of the space, because of it has greater rates of mean (3.4839)equally with ( $\mathrm{P}$ value .026 and .045) while its less striking compare with the most attractive elements of Koya University at rate $(\mathrm{M}=4.1622, \mathrm{P} .000)$ .On the other hands worse elements is availability prances of plants and flowers (D17) which are also ignores from Ishik university with mean rate (2.0323) while its greater than the subordinate element at Koya university at rate $(\mathrm{M}=1.7838, \mathrm{P}$ $.000)$.

Table 5. One sample t-test of Koya university office interior design dimensions

\begin{tabular}{|l|c|c|c|c|c|r|}
\hline $\begin{array}{c}\text { Interior design } \\
\text { dimensions }\end{array}$ & $\mathbf{N}$ & Mean & $\begin{array}{c}\text { Std. } \\
\text { Deviation }\end{array}$ & \multicolumn{1}{c|}{ 仿. (2-tailed) } \\
\hline D1 & 37 & 3.7027 & .96796 & 4.416 & 36 & .000 \\
\hline D2 & 37 & 2.9189 & 1.06402 & $-.464-$ & 36 & .646 \\
\hline D3 & 37 & 3.6757 & .85160 & 4.826 & 36 & .000 \\
\hline D4 & 37 & 3.7297 & 1.01786 & 4.361 & 36 & .000 \\
\hline D5 & 37 & 3.0000 & 1.26930 & .000 & 36 & 1.000 \\
\hline D6 & 37 & 3.3243 & .81833 & 2.411 & 36 & .021 \\
\hline D7 & 37 & 3.0000 & 1.31233 & .000 & 36 & 1.000 \\
\hline D8 & 37 & 1.8378 & .95782 & $-7.380-$ & 36 & .000 \\
\hline D9 & 37 & 3.9459 & 1.17724 & 4.888 & 36 & .000 \\
\hline D10 & 37 & 4.1622 & .92837 & 7.615 & 36 & .000 \\
\hline D11 & 37 & 4.1622 & 1.04119 & 6.789 & 36 & .000 \\
\hline D12 & 37 & 2.8919 & 1.30775 & $-.503-$ & 36 & .618 \\
\hline D13 & 37 & 3.3784 & 1.20994 & 1.902 & 36 & .065 \\
\hline D14 & 37 & 3.2973 & 1.15145 & 1.571 & 36 & .125 \\
\hline D15 & 37 & 2.8108 & 1.22106 & $-.942-$ & 36 & .352 \\
\hline D16 & 37 & 2.6216 & 1.13899 & $-2.021-$ & 36 & .051 \\
\hline D17 & 37 & 1.7838 & 1.13370 & $-6.525-$ & 36 & .000 \\
\hline D18 & 37 & 3.1081 & 1.19684 & .549 & 36 & .586 \\
\hline D19 & 37 & 3.3784 & 1.29853 & 1.772 & 36 & .085 \\
\hline D20 & 37 & 3.5135 & 1.07035 & 2.918 & 36 & .006 \\
\hline D21 & 37 & 2.8649 & 1.25083 & $-.657-$ & 36 & .515 \\
\hline
\end{tabular}

*Item is significant at t.3 p $>0.05$ level (2-tailed).

* The abbreviation (D) is indicated of interior design dimension, for more clarify see appendix A 
Table 6. One-sample t-test of Ishik university interior design elements

\begin{tabular}{|l|c|c|c|c|c|c|}
\hline $\begin{array}{c}\text { Interior design } \\
\text { dimensions }\end{array}$ & $\mathbf{N}$ & Mean & $\begin{array}{c}\text { Std. } \\
\text { Deviation }\end{array}$ & $\mathbf{t}$ & df & Sig. (2-tailed) \\
\hline D1 & 31 & 2.8710 & 1.14723 & $-.626-$ & 30 & .536 \\
\hline D2 & 31 & 2.8387 & 1.09839 & $-.818-$ & 30 & .420 \\
\hline D3 & 31 & 2.8065 & 1.13782 & $-.947-$ & 30 & .351 \\
\hline D4 & 31 & 3.3871 & 1.11587 & 1.931 & 30 & .063 \\
\hline D5 & 31 & 3.3548 & 1.14159 & 1.731 & 30 & .094 \\
\hline D6 & 31 & 2.7097 & 1.07062 & $-1.510-$ & 30 & .142 \\
\hline D7 & 31 & 2.2903 & 1.18866 & $-3.324-$ & 30 & .002 \\
\hline D8 & 31 & 2.1935 & 1.13782 & $-3.946-$ & 30 & .000 \\
\hline D9 & 31 & 3.4839 & 1.28766 & 2.092 & 30 & .045 \\
\hline D10 & 31 & 3.4839 & 1.15097 & 2.341 & 30 & .026 \\
\hline D11 & 31 & 3.2903 & 1.16027 & 1.393 & 30 & .174 \\
\hline D12 & 31 & 2.9677 & .83602 & $-.215-$ & 30 & .831 \\
\hline D13 & 31 & 3.2903 & .82436 & 1.961 & 30 & .059 \\
\hline D14 & 31 & 2.6774 & 1.04521 & $-1.718-$ & 30 & .096 \\
\hline D15 & 31 & 2.7742 & 1.02338 & $-1.229-$ & 30 & .229 \\
\hline D16 & 31 & 2.3871 & 1.14535 & $-2.979-$ & 30 & .006 \\
\hline D17 & 31 & 2.0323 & 1.19677 & $-4.502-$ & 30 & .000 \\
\hline D18 & 31 & 3.2581 & 1.12451 & 1.278 & 30 & .211 \\
\hline D19 & 31 & 3.3226 & .90874 & 1.976 & 30 & .057 \\
\hline D20 & 31 & 3.0968 & 1.01176 & .533 & 30 & .598 \\
\hline & 31 & 2.8387 & 1.12833 & $-.796-$ & 30 & .432 \\
\hline
\end{tabular}

*Item is significant at t.3 p $>0.05$ level (2-tailed).

* The abbreviation (D) is indicated of interior design dimension, for more clarify see appendix A.

On the other hand to test third question and according to one way analysis of variance (ANOVA) of interior design and age ranges $(\mathrm{F}=.613, \mathrm{P}$.919) that shown in the tables (7), that's point to insignificant effect of interior design dimensions on age of employees in each university offices or the interior design of Koya and Ishik university don't effect on any age ranges due to test fourth hypothesis $(\mathrm{H} 4)$.

Table 7. One way analysis of variance (ANOVA) of interior design and age

\begin{tabular}{|l|r|r|r|r|r|}
\hline & Sum of Squares & df & Mean Square & F & Sig. \\
\hline Between Groups & 25.663 & 34 & .755 & .613 & .919 \\
Within Groups & 40.617 & 33 & 1.231 & & \\
Total & 66.279 & 67 & & & \\
\hline
\end{tabular}

*Item is significant $\mathrm{p}<0.05$.

\section{Conclusions}

This research shows that thirteen out of twenty one elements of interior design which are approximately equal to $\% 62$ of them are accessible as well as are share in both Koya and Ishik university offices. Correspondingly, the interior design has an effect on job satisfaction of employee's through their offices in both universities, however the most attractive element of interior design is stating of adequate area of the window compare with the aria of space of room equally but at the different rates, On the other hands, the inferior components which are ignore from both Koya and Ishik university is availability presence of plants and flowers also with deference rates. 
Additionally, there are no effects between the interior design dimensions and ages of employees in both universities. Therefore the interior design has no impacts on any age sorts.

\section{References}

American Society of Interior Designers: ASID (2011) Work place values, American Society of Interior Designers, Ecophon Certainteed, Inc., Haworth, Inc., and Vista Window Film. United States of America.

Berghe, J. A. (2011) Job satisfaction and job performance at the work place, degree thesis at International Business Program.

Çelik, M. (2011) A theoretical approach to the job satisfaction, Polish journal of management studies, Vol. 4.

El-Zeiny, R. M. A. (2013) Interior design of workplace and performance relationship: Private sector corporations in Egypt, Asian Journal of Environmental-Behavior Studies, No. 11.

Giang, N. S. T. and Nguyen, M. T. (2017) An investigation of the impact of interior design of job performance, International Journal of Social Science and Humanity, Vol. 7, No.6.

Guntick, L. (2007) A workplace design that reduces employee stress and increases employee productivity using environmentally responsible materials, master thesis at Michigan University, Ypsilanti, Michigan.

Kamarulzaman, N., Saleh, A. A., Hashim, H. and Abdul-Ghani, A. A. (2011) an over view of the influence of physical office environments towards employees, The 2nd International Building Control Conference, Elsevier Ltd.

Leblebici, D. (2012) Impact of workplace quality on employee's productivity, Journal of Business, Economics \& Finance, Vol.1 (1).ISSN:2146-7943.

Mustafa, F. A. (2017) Performance assessment of building via post occupancy evaluation, Frontiers of Architectural Research, Vol. 6, Pp. 412-429.
Neog, B. B. and Barua, M. (2014) factors influencing employee's job satisfaction, The SIJ Transactions on Industrial, Financial \& Business Management (IFBM), Vol. 2, No. 7.

Walker, A. and Sorce, P. (2009) correlates of job satisfaction of early career employees in printing and publishing occupations, Printing Industry Center at RIT Rochester, NY.

\section{Appendix A.}

D1:Office lay out (Office design)

D2:Quality and arrangement of the Furniture

D3:Office comfortably

D4:The cleanness of the office.

D5:Quality of communications

D6:Privacy of workplace

D7:Personal storage.

D8:Daily music in the office

D9:The amount of natural lighting:

D10:Adequate area of the window, in compare with the area of the space .

D11:The location of the window.

D12:Physical security (Fire safety)

D13:Temperature and thermal comfort in the office .

D14:Is it appropriates the special arrangement of the office, like furniture arrangement, proportion and the dimensions of the room.

D15:Harmonize office colors.

D16:decorative scheme

D17:Presence of plants and flowers.

D18:Natural ventilation

D19:Heating, thermal comfort and air conditioning in the office

D20:Acoustical comfort and noise.

D21:Fire resistance material for fire safety 
(JPMNT) Journal of Process Management - New Technologies, International Vol. 6, No 2, 2018. 